\title{
Short-term assessment of the sediment deposition rate and water conditions during a rainy season on La Azufrada coral reef, Gorgona Island, Colombia
}

\author{
Diego F. Lozano-Cortés ${ }^{1}$, Alan Giraldo ${ }^{1,2 *}$ \& Vanessa Izquierdo ${ }^{1}$ \\ 1. Universidad del Valle, Departamento de Biología, Grupo de Investigación en Ecología de Arrecifes Coralinos. Calle \\ 13 No. 100 - 00. Cali, Colombia; diegoflc@gmail.com; vaneizqpe@gmail.com \\ 2. Universidad del Valle, Departamento de Biología, Grupo de Investigación en Ciencias Oceanográficas, Calle 13 No. \\ 100-00. Cali, Colombia; alan.giraldo@correounivalle.edu.co; oceanografía@univalle.edu.co
}

Recibido 18-X-2013. Corregido 20-XI-2013. Aceptado 19-XII-2013.

\begin{abstract}
One of the major stresses on corals is the settlement of suspended sediment on their surfaces. This leads to the blocking of light, the covering of the coral mucus surface and an increased risk of disease. For this reason sediment deposition on a reef is considered a highly important variable in coral reef studies. With the use of sediment traps and oceanographic sensors, the sediment deposition rate and water conditions during a rainy season (April-May 2009) on a Tropical Eastern Pacific coral reef (La Azufrada) at Gorgona Island in Colombia were investigated. To quantify sediment deposition, sediment traps were established in nine stations along the coral reef (three stations per reef zone: backreef, flat and slope). To minimize disturbance by aquatic organisms in the sediment traps these were filled with hypersaline borax-buffered $10 \%$ formaline solution before their deployment; animals found in the filter contents were fixed and stored in a $4 \%$ formalin solution, frozen and identified in the laboratory. To determine the water conditions, discrete samples of water from $1 \mathrm{~m}$ and $10 \mathrm{~m}$ depths were collected using a Niskin bottle. Oceanographic variables (temperature, salinity and dissolved oxygen) as well as turbidity, chlorophyll and nutrient concentration (nitrite, nitrate and phosphorus) were measured in the samples from both depths. Vertical records of temperature and salinity were carried out with a Seabird-19 CTD nearest to La Azufrada and water transparency was measured using a Secchi disk. We found a mean trap collection rate of $23.30 \pm 4.34 \mathrm{gm}^{-2} \mathrm{~d}^{-1}$ and did not detect a significant difference in the trap collection rate among reef zones. The mean temperature and salinity in the coral reef depth zone $(0-10 \mathrm{~m}$ layer $)$ were $26.98 \pm 0.19^{\circ} \mathrm{C}$ and $32.60 \pm 0.52$, respectively. Fourteen taxonomic groups of invertebrates were detected inside the sediment traps with bivalves and copepods being the most abundant and frequen. The findings presented here constitute the first report of both the potential sediment deposition rates and the water conditions of La Azufrada coral reef. Rev. Biol. Trop. 62 (Suppl. 1): 107-116. Epub 2014 February 01.
\end{abstract}

Key words: sediment deposition, coral reefs, oceanographic conditions, invertebrates, Tropical Eastern Pacific, Gorgona Island, Colombia.

Coral reefs represent an important biological, economical and cultural resource, providing sources of food, building material and revenue through tourism and fisheries (Birkeland, 1997; Rees, Opdyke, Wilson \& Fifield, 2005). Reefs also act as a natural defense barrier for coastal areas which often support high biodiversity (Bellwood \& Hughes, 2001). The health and survival of reefs around the world are undoubtedly already under threat by both man-made and naturally occuring destructive forces. These include terrestrial runoff, increased turbidity, pollution, siltation, coral bleaching and abnormal inputs of nutrients and organic matter (Acevedo \& Morelock, 1988; Roberts et al., 2002; Rees et al., 2005).

One of the most serious dangers to coral reefs is sediment deposition which covers potential recruitment habitats, intensifies competition for space on the benthos and eventually leads to coral bleaching, tissue necrosis and colony death (Hubbard, 1986; Zapata \& Vargas-Ángel, 2003). Sedimentation and suspended sediment in the water column may 
affect coral populations and community structure by smothering adult corals, reducing light availability for photosynthesis or increasing the need for active sediment removal, thus imposing physiological costs on the organism (Babcock \& Smith, 2000; Storlazzi, Ogston, Bothner, Field \& Presto, 2004). Although corals exhibit different mechanisms to ride theselves of sediment [increased tentacular activity, mucus production and tissue expansion by active uptake of water (Rogers, 1990)], sediment deposition has been recognized as a major factor controlling the distribution of reef organisms and overall reef development. Moreover, sedimentation is regarded as the major cause of worldwide coral reef degredation (Rogers, 1990; McClanahan \& Obura, 1997).

Gorgona Island, which houses the largest and most continuous fringing reefscape on the Pacific coast of Colombia (Zapata \& VargasÁngel, 2003), has not been exempt from disturbance caused by sediment depostion. As this island was Colombia's top security prison from 1960 to 1983 , the reefs have suffered extensive coral death. This is most notably observed on the backreef of La Azufrada as a consequence of sediment accumulation caused by runoff from unstable upper soils due to indiscriminate excavation for the construction of the airport landing strip (Prahl, Guhl \& Grogl, 1979). Even after more than 25 years of natural island reforestation, corals at La Azufrada reef are still covered with a fine layer of sediment (Zapata \& Vargas-Ángel, 2003) and in accordance with Zapata, Rodríguez-Ramírez $\&$ Navas-Camacho (2008), 38.3\% of the live coral cover in La Azufrada reef was lost during the decade 1998-2007.

To date, no scientific reports about water conditions or the sediment effects on the structure of La Azufrada coral reef have been published. Furthermore, reports about sedimentation rate are scarce. In the present study, we describe the physical and chemical conditions of the water column in addition to measuring the sediment depostion rate as a function of the trap collection rate in La Azufrada reef during a 2009 rainy season. Specifically, we (1) evaluate the small scale variability of temperature and salinity around La Azufrada reef; (2) measure the potential short-term sediment deposition rate on the main physiographic zones of the reef: backreef, flat and slope, (3) relate those variables to the coral stress level and (4) describe the macroinvertebrate assemblage associated with sediment trap deployment at La Azufrada reef.

\section{MATERIALS AND METHODS}

Study Area: Gorgona National Natural Park is a continental island located $35 \mathrm{~km}$ off the Colombian Pacific coast $\left(2^{\circ} 58^{\prime} 00^{\prime \prime} \mathrm{N}\right.$

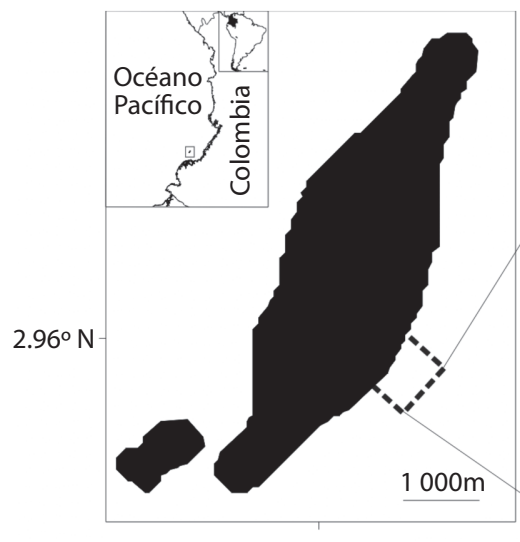

$78.19^{\circ} \mathrm{W}$

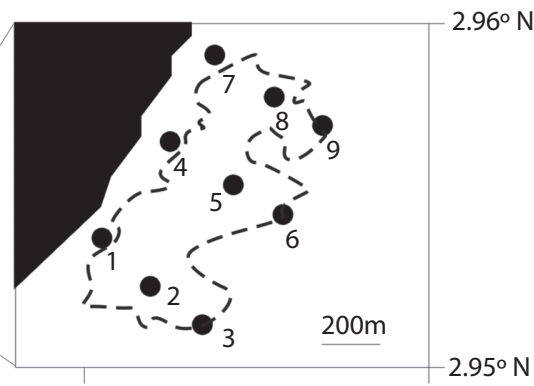

$78.18^{\circ} \mathrm{W}$

$78.17^{\circ} \mathrm{W}$

Fig. 1. Geographic location of Gorgona Island and sampling grid (stations) on La Azufrada coral reef. 
- 78 11'24' W; Fig. 1) within the area of influence of the Intertropical Convergence Zone (ITCZ). The periodical displacement of the ITCZ produces a bimodal pattern of precipitation at Gorgona (mean annual precipitation $\sim 6700 \mathrm{~mm}$ ) with a wetter season between May and October. Even though sea surface temperatures around Gorgona are normally between $26-29^{\circ} \mathrm{C}$ (within the range of temperatures for vigorous coral growth and reef development), occasional temperatures lower than $19^{\circ} \mathrm{C}$ and higher than $32^{\circ} \mathrm{C}$ can be recorded mainly during La Niña and El Niño events. Salinity (30-33) and water clarity ( $<5-25 \mathrm{~m}$ visibility) are decreased by the freshwater input caused by the abundant rain. The eastern coast of the island has two main fringing reefs and several patch reefs dominated by branching corals of the genus Pocillopora (Glynn, Prahl \& Guhl, 1982; Prahl \& Erhardt 1985). Glynn et al. (1982), Zapata \& Vargas-Ángel (2003), Giraldo (2008) and Giraldo, Rodríguez-Rubio \& Zapata (2008) give details about coral formations, as well as oceanographic and physical conditions around Gorgona Island.

Water conditions: The assessment of water conditions on La Azufrada reef was carried out using the data collected during an oceanographic sampling conducted near to the reef $(<100 \mathrm{~m})$. In this station, a discrete sample of water from $1 \mathrm{~m}$ and $10 \mathrm{~m}$ depth was collected using a Niskin bottle. Temperature, salinity and dissolved oxygen were measured using an YSI 85 multi parameter probe in both water samples. Furthermore, three water aliquots from both depths were taken in order to measure in situ turbidity and chlorophyll using an AquaFluor ${ }^{\circledR}$ field fluorometer. A Spectroquant ${ }^{\circledR}$ Merck was used to determine nutrient concentration (nitrite, nitrate and phosphorus). Vertical records of temperature and salinity were carried out with a Seabird-19 CTD unit and water transparency was measured using a Secchi disk. A t-test was used to evaluate differences in chlorophyll-a and turbidity between $0 \mathrm{~m}$ and $10 \mathrm{~m}$ depths.
Sediment deposition: Sediment deposition rate was measured as a function of the trap collection rate, following methods used by Chou, Yu \& Loh (2004), Dikou \& Van Woesik (2006), Maldonado, Giraud \& Carmona (2008) and Storlazzi, Field \& Bothner (2011), with some modifications. We established nine stations along the coral reef (three stations per reef zone: backreef, flat and slope) and deployed sediment traps at each station $(8 \mathrm{~cm}$ diameter: $21 \mathrm{~cm}$ heights; collector area: $54.7 \pm 0.8 \mathrm{~cm}^{2}$ ) placed $20 \mathrm{~cm}$ above the seabed. One trap consisting of a $2 \mathrm{~L}$ plastic bottle was tied to a stainless steel rod and held in position by plastic bands. A replica was set $1 \mathrm{~m}$ apart at each station (nine stations, 18 traps, six per reef zone), allowing us to evaluate the reproducibility of the collection rate measurement (Bothner, Reynolds, Casso, Storlazzi \& Field, 2006).

Sediment traps were deployed on April $29^{\text {th }} 2009$, and were collected two days after, on May $1^{\text {st }} 2009$; the total exposure time was $44.3 \pm 0.6 \mathrm{~h})$. Every trap was filled with hypersaline borax-buffered $10 \%$ formaline solution before their deployment to minimize disturbance by aquatic organisms. The animals found in the filter contents were fixed and stored in a $4 \%$ formalin solution and frozen until identification was done. In the laboratory every individual was classified by taxonomic group according to Young, Sewell \& Rice (2002). The sample design allowed us to compare the abundance (one way ANOVA) and diversity (Shannon index) between reef zones.

Trap contents, including all suspended particles, were filtered in a manifold with a vacuum bomb using pre-weighed cellulose filters $(52 \mathrm{~mm})$ which were then dried at $65^{\circ} \mathrm{C}$ for $24 \mathrm{~h}$ and weighed again. The sediments were then removed from the cellulose filters to pre-weighed Whatman GFF filters $(42 \mathrm{~mm})$ and combusted to ash at $450^{\circ} \mathrm{C}$ for $5 \mathrm{~h}$. The dry weight of the sediment samples was used to estimate the average trap collection rate (g dry sediment per $\mathrm{m}^{2}$ and day), while weight differences between dried and combusted samples allowed us to estimate mean organic content 
of the sediment entering the traps (\% organic matter weight relative to dry sediment weight; Maldonado et al., 2008). A Kruskall Wallis test (KW) was used to evaluate differences in sediment deposition rate among backreef, flat and slope. A Dunn test (multiple t-test postanova) was carried out between each possible pair among the group (reef zones) when differences between the treatments were found.

\section{RESULTS}

A mean trap collection rate of $23.30 \pm 4.34 \mathrm{~g}$ $\mathrm{m}^{-2} \mathrm{~d}^{-1}$ (mean \pm confidence interval) was found for La Azufrada reef. Reproducibility of the collection-rate measurement by tube traps on each reef zone was $39 \%, 32 \%$ and $26 \%$, respectively. In each reef zone the sediment deposition rate was highly variable. The particulate inorganic material deposition rate in the backreef ranged from 23.86 (20.42-29.38) $\mathrm{g} \mathrm{m}^{-2} \mathrm{~d}^{-1}$ [median (25\%-75\%)], in the flat zone from 18.29 (16.81-23.44) $\mathrm{g} \mathrm{m}^{-2} \mathrm{~d}^{-1}$, and in the slope from $23.70(19.16-29.32) \mathrm{g} \mathrm{m}^{-2}$ $\mathrm{d}^{-1}$. However, no significant differences were detected (K-W, $\mathrm{H}=0.38$, $\mathrm{p}=0.85$, Fig. 2 ). On the other hand, when the particulate organic material contribution to the collected sediment was evaluated, we detected differences between the backreef and the slope zones (KW, $\mathrm{H}=9.96$, $\mathrm{p}=0.007$, Table 1).

Physical and chemical measurements were similar to "normal conditions" previously reported for Gorgona Island (Giraldo 2008, Giraldo et al. 2008). Mean temperature and salinity in the coral reef depth zone $(0-10 \mathrm{~m}$ layer) were $26.98 \pm 0.19^{\circ} \mathrm{C}$ and $32.60 \pm 0.52$, respectively. The water column around $\mathrm{La}$ Azufrada reef was stratified with a sharp thermocline (isotherm $21^{\circ} \mathrm{C}$ ) at $17 \mathrm{~m}$ depth (Fig. 3).

Physical and chemical conditions were in the optimal range for growth and development of coral reefs (Table 2; see Table 1 in Szmant, 2002). However, turbidity and chlorophyll-a concentration were above the threshold for optimal coral reef conditions. Although, we did not detect a significant difference in chlorophyll-a concentration between surface $(0 \mathrm{~m})$ and $10 \mathrm{~m}$ depth in La Azufrada reef (t-test. $\mathrm{t}=2.55, \mathrm{p}=0.06$ ), a significant turbidity difference was detected between surface and $10 \mathrm{~m}$ depth (t-test, t=56.90, p $<0.001 ;$ Fig. 4)

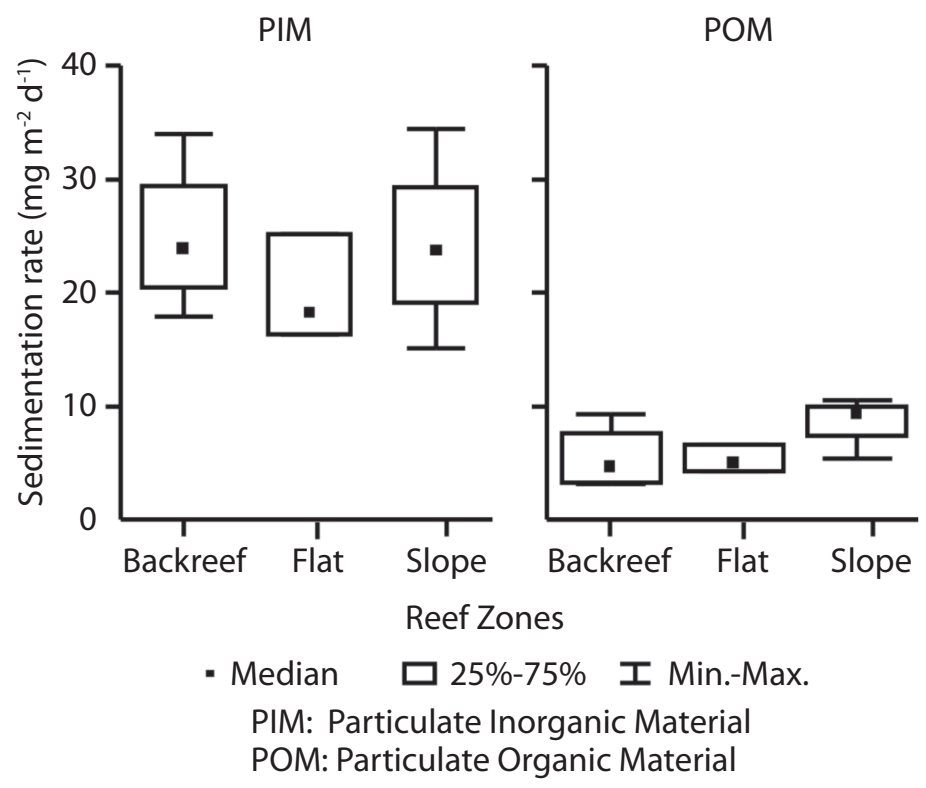

Fig. 2. Organic/inorganic fraction in the sediment from nine stations on the reef zones in La Azufrada reef, Gorgona Island. 
TABLE 1

Particulate organic material contribution (\%) in sediment collected in the backreef, flat and slope of La Azufrada Reef, Gorgona Island, Colombia. Q: Dunn test, p: p-value

\begin{tabular}{lcccc}
\multicolumn{1}{c}{ Zone } & Median $(25 \%-75 \%)$ & Dunn test & Q & P \\
Backreef & $16.4(13.7-19.4)$ & Slope-Backreef & 3.12 & $<0.05$ \\
Flat & $23.2(20.3-24.2)$ & Slope-Flat & 1.40 & $>0.05$ \\
Slope & $27.1(24.9-28.3$ & Flat-Backreef & 1.77 & $>0.05$ \\
\hline
\end{tabular}

TABLE 2

Physical and chemical conditions of the water column (0m and 10m) at La Azufrada coral reef, Gorgona Island

\begin{tabular}{|c|c|c|c|c|}
\hline Variables & & $0 \mathrm{~m}$ & $10 \mathrm{~m}$ & Thresholds \\
\hline Temperature $\left({ }^{\circ} \mathrm{C}\right)$ & & 27.2 & 26.6 & NA \\
\hline Salinity & & 32.2 & 33.3 & NA \\
\hline Dissolved Oxygen $\left(\mathrm{ml} \mathrm{L}^{-1}\right)$ & & 4.92 & 4.83 & NA \\
\hline Turbidity (NUT) & & $4.24 \pm 0.11$ & $0.43 \pm 0.04$ & NA \\
\hline Chlorophyll (ug L $\left.\mathrm{g}^{-1}\right)$ & & $0.97 \pm 0.07$ & $0.73 \pm 0.15$ & $0.5 u \mathrm{~g} \mathrm{~L}^{-1}$ \\
\hline $\mathrm{PO}_{4}(u \mathrm{M})$ & & 0.21 & 0.19 & $0.20 U \mathrm{~m}$ \\
\hline $\mathrm{NO}_{2}(u \mathrm{M})$ & & 0.04 & 0.04 & \multirow{2}{*}{$1.0 u \mathrm{M}$} \\
\hline $\mathrm{NO}_{3}(u \mathrm{M})$ & & 0.24 & 0.19 & \\
\hline Secchi depth (m) & 5.0 & & & \\
\hline Thermocline depth (m) & 17 & & & \\
\hline
\end{tabular}

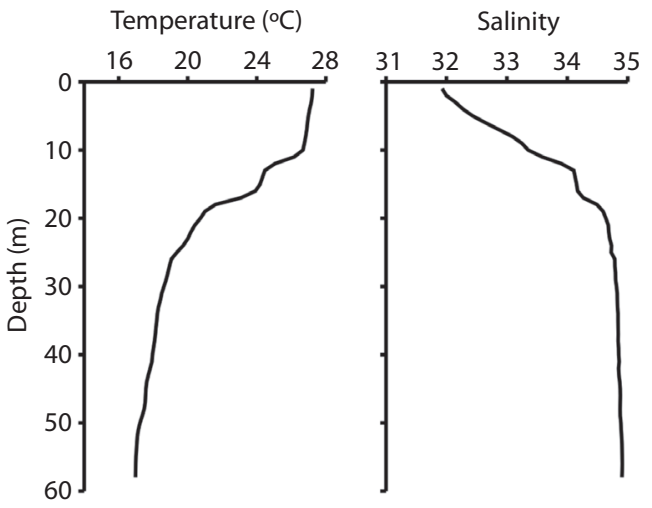

Fig. 3. Surface vertical profiles $(<60 \mathrm{~m})$ of temperature and salinity obtained nearest $(<100 \mathrm{~m})$ to La Azufrada coral reef, Gorgona Island.

The fauna collected in the sediment traps was composed of fourteen taxonomic groups (Table 3). Bivalves were the most abundant group (39.3\% of the whole sample) followed by copepods $(23.8 \%)$. The most frequent groups were copepods $(100 \%)$, bivalves (71\%) and shrimps (71\%). There was no difference between abundance $(\mathrm{KW}, \mathrm{p}=0.21)$ or diversity $(\mathrm{KW}, \mathrm{p}=0.66)$ in the traps between the reef zones.

\section{DISCUSSION}

The mean sediment deposition rate estimated for La Azufrada reef is in accordance with the "normal" sedimentation rate expected on a coral reef $\left(<100 \mathrm{~g} \mathrm{~m}^{-2} \mathrm{~d}^{-1}\right.$, Rogers, 1990). Furthermore, it was equivalent to the $10 \%$ of sediment tolerance limit $\left(300 \mathrm{~g} \mathrm{~m}^{-2} \mathrm{~d}^{-1}\right)$ proposed for fringing reefs by Hawker \& Connell (1992) mentioned by Dikou \& Van Woesik (2006). Cantera et al. (2003) reported a complex spatial pattern of sedimentation for Playa Blanca reef (a coral reef adjacent to La Azufrada). These authors found a lower sediment deposition rate on the slope $\left(10.28 \mathrm{~g} \mathrm{~m}^{-2} \mathrm{~d}^{-1}\right)$ than on the backreef $\left(29.38 \mathrm{~g} \mathrm{~m}^{-2} \mathrm{~d}^{-1}\right)$; results that support the idea that terrestrial runoff from the island should be the main source of sediment in this reef (Zapata, 2001). Although our estimation of the sediment deposition rate on 

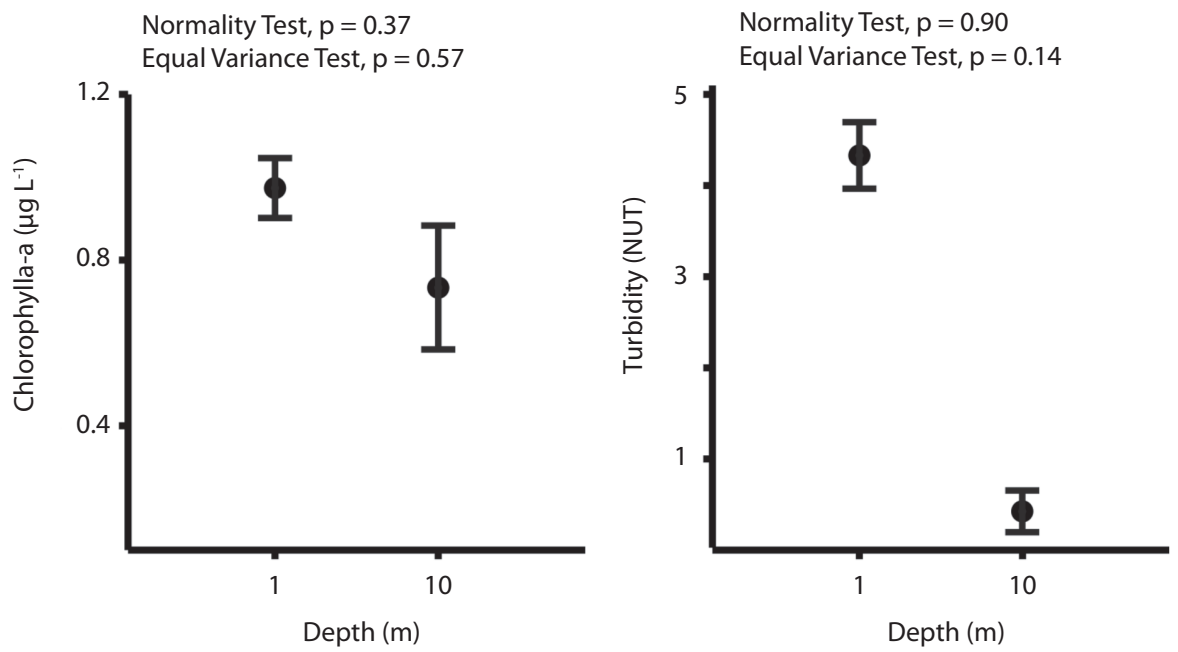

Fig. 4. Chlorophyll-a and turbidity in La Azufrada coral reef at Gorgona Island, Colombia.

TABLE 3

Invertebrate fauna composition collected in the sediment traps deployed at La Azufrada coral reef, Gorgona Island. Mean number of individual by trap. $n=$ total number of sediment traps considered per reef zone. $\%=$ percentage of the total composition

\begin{tabular}{lccccc}
\multicolumn{1}{c}{ Taxonomic group } & Backreef $(\mathrm{n}=4)$ & Flat $(\mathrm{n}=3)$ & Slope $(\mathrm{n}=4)$ & Total $(\mathrm{n}=11)$ & $\%$ \\
Bivalves & 12.8 & 5.7 & 14.8 & 11.5 & 39.3 \\
Copepods & 10.0 & 7.3 & 3.8 & 7.0 & 23.8 \\
Ciirripedia & 3.0 & 3.0 & 3.0 & 2.9 & 9.9 \\
Shrimps & 2.5 & 0.7 & 2.0 & 1.8 & 6.2 \\
Gasteropoda & 1.8 & 1.7 & 1.8 & 1.7 & 5.9 \\
Megalops & 0.3 & 0.3 & 4.3 & 1.7 & 5.9 \\
Amphipods & 0.8 & 0.3 & 0.8 & 0.6 & 2.2 \\
Nauplius & 0.3 & 0.0 & 1.3 & 0.5 & 1.9 \\
Mysids & 0.8 & 0.0 & 0.3 & 0.4 & 1.2 \\
Euphausiids & 0.5 & 0.3 & 0.0 & 0.3 & 0.9 \\
Not Identified & 0.3 & 0.3 & 0.3 & 0.3 & 0.9 \\
Cumaceans & 0.3 & 0.0 & 0.3 & 0.2 & 0.6 \\
Ophiuridae & 0.3 & 0.3 & 0.0 & 0.2 & 0.6 \\
Holothuridae & 0.3 & 0.0 & 0.0 & 0.1 & 0.3 \\
Cladocerans & 0.0 & 0.3 & 0.0 & 0.1 & 0.3 \\
\hline
\end{tabular}

the backreef was similar to the one reported by Cantera, Orozco, Londoño-Cruz \& ToroFarmer (2003), on the slope zone the trap collection rate was threefold higher. This temporal difference may suggest that some years later not only sediments derived from Gorgona itself are arriving to La Azufrada reef, but also sediment from the mainland could be affecting the reef simultaneously. However, this should be confirmed with upcoming and more meticulous studies (e.g. monthly sampling, rainy and less rainy seasons) considering that results presented herein were obtained from a single sampling time point conducted during the rainy season and furthermore the methods used in this study differ from those used by Cantera et al. (2003).

In the last decade the coral cover on Gorgona Island reefs has decreased by $38.3 \%$ 
(Zapata et al., 2008) and it has been suggested that sedimentation stress may explain the coralalgal dynamics in this environment (Zapata et al. 2010). Apparently, this coral cover decrease could be connected to an increase in the net sediment deposition rate. Therefore, future research projects should ascertain the origin of this sediment (whether it's from island runoff or if it has been transported from the mainland) because it has been reported that terrigenous sediment discharge reduces coral growth and coral reef biodiversity (Acevedo \& Morelock, 1988; Rogers, 1990; Fabricius, 2005). In this sense, the nearest potential mainland source of sediment to Gorgona is the Patía Sanquianga river delta (c.a. $<50 \mathrm{~km}$ ), with a

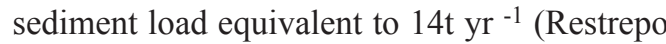
\& Kjerfve, 2000).

The influence of mainland waters (Patia Sanquianga river plume) or runoff waters into La Azufrada reef could be modulated by local weather conditions. Two main climatic seasons have been described in Gorgona: a rainy period from May to November (c.a. $>500 \mathrm{~mm} \mathrm{month}^{-1}$ ) and a less rainy period from December to April (c.a. $<500 \mathrm{~mm} \mathrm{month}^{-1}$; Blanco, 2009). Therefore, a seasonal variation in sediment deposition, water transparency, nutrient availability, and sea surface temperature and salinity would be expected. The present study was carried out during the rainy season, where the influence of mainland waters is greater than in the less rainy season. Therefore, the concentration of nutrients and particulate matter in the water column will be higher and reduction in water column transparency and the growth of benthic macro-algae would be expected. These environmental conditions favour the growth of coral competitors, especially those that bore into coral skeletons, such as endolithic bioeroders, sponges, molluses, worms and burrowing algae; and probably make corals more susceptible to diseases (Spencer \& Viles, 2002; Wilkinson, 2004).

The zooplankton and fish actively access the inside of the sediment traps (Silver, Pilskaln \& Steinberg, 1991, Steingber, Pilskaln \& Silver, 1998, Buesseler et al., 2000; Kraft et al., 2012). Some of those organisms would be considered intruders (e.g. Ophiuridae, shrimp and fish) and some genuinely associated with detritus (e.g. bivalves, copepods or amphipods) that is immersed in the material collected inside the trap (Silver \& Gowing, 1991; Kraft et al., 2012). Moreover, the sediment trap could have provided a new habitat or sheltered environment for some zooplankton and fishes where abundant food sources can be found (Kraft et al., 2012). Although the fauna associated with sediment in the eastern Tropical Pacific coral reef areas have not been extensively studied, recent research suggests that the factors responsible for the community structure in this environment is related to sediment characteristics, hydrodynamic conditions and specific region/ habitat features (Semprucci et al., 2010; 2013). For instance, under a low flow regime of organic matter deposition, sediment-dwelling taxa (nematodes and annelids) are favored, while in a habitat dominated by rubble and dead coral fragments, there may be an increase in copepods and ostracods associated to soft bottom sediment areas (Semprucci et al., 2013). Therefore, inside a sediment trap deployment in a tropical coral reef the dominant fauna would be filter-feeder (e.g. bivalve) and dretitus-feeder (e.g. copepods), such as those groups that were dominant in this study.

Sediment traps have been used over the years to acquire a representative sample of the material settling vertically through the water column and to provide integrated particle collection rates and particle properties over the time of deployment (Rogers, Garrison, Grober, Hillis \& Franke, 1994; Almada-Villela, Sale, Gold-Bouchot \& Kjerfve, 2003; Bothner et al., 2006). In fact, now sediment traps in coral reef environments are being used as a standard method for monitoring the effects of sediment on coral reefs and as a method for determining the impact or effectiveness of land-use practices (Wilkinson, Green, Almany \& Dionne, 2003; Hill \& Wilkinson, 2004; Jordan Banks, Fisher, Walker \& Gilliam, 2010). However, the information derived from sediment traps have been misinterpreted because 
of a lack of understanding of the trap design and the deployment method for the type and the amount of material being collected. It also has been misapplied due to a failure to understand the sediment and sediment trap dynamics in the shallow-water environment associated with the coral reef (Storlazzi et al., 2011). These two things must be taken into account when implementing this method in a coral reef health monitoring program.

In summary, the findings presented here constitute the first effort to describe the water conditions at La Azufrada coral reef and this is also the first report of potential sediment deposition rate in this important ecosystem at Gorgona Island. These results can be used as a baseline for future research, although further comprehensive studies (e.g. considering seasonal variation and sediment re-suspension) must be applied to reef monitoring and management practices. Research addressed to clarify the origin of the sediments (i.e. transported by river plume from the mainland or runoff waters from the island itself), and comparisons between rainy versus less rainy season (high precipitation may alter the sediment budget and generate a different spatial sediment deposition pattern) will be valuable for knowledge of the sediment dynamics at La Azufrada reef. This will provide useful information for the conservation of this valuable ecosystem.

\section{ACKNOWLEDGMENTS}

We thank Diego Ramírez, Jose Luis García, and Isabel Ocampo for their support during the field work and data collection. Special thanks to Emily Giles (King Abdullah University of Science and Technology) for correcting the English manuscript. This work was financed by Universidad del Valle and the Henry von Prahl Research Station (Parque Nacional Natural Gorgona). Research permit No DTSO-G-05 03/08 to A.G.

\section{RESUMEN}

Uno de los principales factores de estrés en los corales es el asentamiento de sedimento suspendido sobre su superficie. Esto conlleva al bloqueo de la luz, el cubrimiento superficial del mucus coralino e incremento del riesgo de enfermedades. Por esta razón, la sedimentación en considerada como un variable de alta importancia en el estudio de los arrecifes coralinos. Por medio de trampas de sedimentación (en nueve estaciones: seis por zona arrecifal), este proceso fue estudiado en un arrecife coralino (La Azufrada) del Pacífico Oriental Tropical, localizado en Isla Gorgona, Colombia. En las trampas se encontró una tasa promedio de colecta de sedimento de $23.30 \pm 4.34 \mathrm{gm}^{-2} \mathrm{~d}^{-1}$ a y no se detectaron diferencias significativas entre las zonas arrecifales. La temperatura promedio y salinidad de la columna de agua donde habitan corales en este arrecife (entre 0 y $10 \mathrm{~m}$ ) fue $26.98 \pm 0.19^{\circ} \mathrm{C}$ y $32.60 \pm 0.52$, respectivamente. Catorce grupos taxonómicos de invertebrados fueron encontrados en las trampas de sedimentación. Los bivalvos y copépodos fueron los más abundantes y frecuentes. Los resultados presentados constituyen el primer reporte de la tasa de deposición de sedimentos y de las condiciones del agua en La Azufrada. Estos resultados representan una línea base para estudios posteriores, aunque se necesita más investigación sobre estos temas que son esenciales para el manejo de los arrecifes coralinos.

Palabras clave: deposición de sedimentos, arrecifes de coral, condiciones oceanográficas, invertebrados, Pacífico Oriental Tropical, Isla Gorgona, Colombia.

\section{REFERENCES}

Acevedo, R. \& Morelock, J. (1988). Effects of terrigenous sediment influx on coral reef zonation in southwestern Puerto Rico. Proceedings 6th International Coral Reef Symposium, 2: 92-100.

Almada-Villela, P. C., Sale, P. F., Gold-Bouchot, G. \& Kjerfve, B. (2003). Manual of methods for the Mesoamerican barrier reef systems synoptic monitoring program: Selected methods for monitoring physical and biological parameters for use in the Mesoamerican region. Belize City: Mesoamerican Barrier Reef Systems Project Coordinating Unit.

Babcock, R. \& Smith, L. (2000). Effects of sedimentation on coral settlement and survivorship. Proceedings 9th International Coral Reef Symposium, 1: 23-27.

Blanco, J. F. (2009). The hydroclimatology of Gorgona Island: seasonal and Enso-related patterns. Actualidades Biológicas, 31: 111-121.

Bellwood, D. R. \& Hughes, T. P. (2001). Regional scale assembly rules and biodiversity of coral reefs. Science, 292: 1532-1535 
Birkeland, C. (1997). Life and death of coral reefs. New York: Chapman and Hall.

Bothner, M. H., Reynolds, R. L., Casso, M. A., Storlazzi, C. D. \& Field, M. E. (2006). Quantity composition and source of sediment collected in sediment traps along the fringing coral reef off Molokai, Hawaii. Marine Pollution Bulletin, 52: 1034.1047.

Buesseler, K. O., Steinberg, D. K., Michaels, A. F., Johnson, R. J., Andrews, J. E., Valdes J. R. \& Price, J. F. (2000). A comparison of the quantity and composition of material caught in a neutrally buoyant versus surface-tethered sediment trap. Deep Sea Research Part I, 47: 277-294.

Cantera, J., Orozco, C., Londoño-Cruz, E. \& Toro-Farmer, G. (2003). Abundance and distribution patterns of infaunal associates and macroborers of the branched coral (Pocillopora damicornis) in Gorgona Island (Eastern Tropical Pacific). Bulletin of Marine Science, 72: 207-219.

Chou, L., Yu, J. \& Loh, T. (2004). Impacts of sedimentation on soft-bottom benthic communities in the southern islands of Singapore. Hidrobiología, 515: 91-106.

Dikou, A. \& Van Woesik, R. (2006). Survival under chronic stress from sediment load: Spatial patterns of hard coral communities in the southern islands of Singapore. Marine Pollution Bulletin, 52: 7-21.

Fabricius, K. E. (2005). Effects of terrestrial runoff on the ecology of corals and coral reefs: review and synthesis. Marine Pollution Bulletin, 52: 125-146.

Giraldo, A. (2008). Variabilidad espacial de temperatura, salinidad y transparencia en el ambiente pelágico del PNN Gorgona durante septiembre 2007 y marzo 2008. Boletín Cientifico. Centro de Investigaciones Oceanográficas e Hidrográficas del Caribe, 26: 157-163.

Giraldo, A., Rodríguez-Rubio, E. \& Zapata, F. A. (2008). Condiciones oceanográficas en Isla Gorgona, Pacífico oriental tropical de Colombia. Latin American Journal of Aquatic Research, 36: 121-128.

Glynn, P. W., Prahl, H. \& Guhl, F. (1982). Coral reefs of Gorgona Island, with special reference to corallivores and their influence on community structure and reef development. Anales del Instituto de Investigaciones Marinas de Punta de Betín, 12: 185-214.

Hawker, D.W. \& Connell, D. W. (1992). Standards and Criteria for pollution control in coral reef areas. In: D. W. Connell \& D. W. Hawker, (Eds.), Pollution in Tropical Aquatic Systems, CRC Press, Australia.

Hill, J. \& Wilkinson, C. (2004). Methods for ecological monitoring of coral reefs, version 1 . A resource for managers. Townsville: Australian Institute of Marine Science.
Hubbard, D. K. (1986). Sedimentation as a control of reef development: St Croix, U.S. Virgin Islands. Coral Reefs, 5: 117-126.

Jordan, L. K. B., Banks, K. W., Fisher, L. E., Walker, B. K. \& Gilliam, D. S. (2010). Elevated sedimentation on coral reefs adjacent to a beach nourishment project. Marine Pollution Bulletin, 60: 261-271.

Kraft, A., Bauerfeind, E., Nöthig, E. \& Bathmann, U. V. (2012). Size structure and life cycle patterns of dominant pelagic amphipods collected as swimmers in sediment traps in the eastern Fram Strait. Journal of Marine Systems, 95: 1-15.

Maldonado, M., Giraud, K. \& Carmona, C. (2008). Effects of sediment on the survival of asexually produced sponge Recruits. Marine Biology, 154: 631-641.

McClanahan T. R. \& Obura, D. (1997). Sedimentation effects on shallow coral communities Kenya. Journal of Experimental Marine Biology and Ecology, 209: 103-122.

Prahl, H., Guhl, F. \& Grogl, M. (1979). Gorgona. Bogotá: Grupo Editorial Futura LTD.

Prahl, H. \& Erhardt, H. (1985). Colombia: corales y arrecifes coralinos. Fondo FEN-Colombia. Bogotá: Editorial Presencia.

Rees, S., Opdyke, B., Wilson, P. \& Fifield, L. (2005). Coral reef sedimentation on Rodrigues and the Western Indian Ocean and its impact on the carbon cycle. The Royal Society biological Sciences, 363: 101-120.

Restrepo, J. D. \& Kjerfve, B. (2000). Water Discharge and Sediment Load from the Western Slopes of the Colombian Andes with Focus on Rio San Juan. The Journal of Geology, 108: 17-23.

Roberts, C. M., McClean, C. J., Veron, J. E., Hawkins, J. P., Allen, G. R., McAllister, D. E., Mittermeier, C. G., Schueler, F. W., Spalding, M., Wells, F., Vynne, C. \& Werner T. B. (2002). Marine biodiversity hotspots and conservation priorities for tropical reefs. Nature, 295: 1280-1284.

Rogers, C. S. (1990). Responses of coral reefs and reef organisms to sedimentation. Marine Ecology Progress Series, 62: 185-202.

Rogers, C. S., Garrison, G., Grober, R., Hillis, Z. M. \& Franke, M. A. (1994). Coral reef monitoring manual for the Caribbean and Western Atlantic. Virgin Islands: USA. National Park Service.

Semprucci, F., Colantoni, P., Baldelli, G., Rocchi, M. \& Balsamo, M. (2010). The distribution of meiofauna on back-reef sandy platforms in the Maldives (Indian Ocean). Marine Ecology, 31: 592-607.

Semprucci, F., P. Colantoni, G. Baldelli, G., C. Sbrocca, M. Rocchi \& C. Balsamo. (2013). Meiofauna associated with coral sediments in the Maldivian subtidal habitats (Indian Ocean). Marine Biodiversity, 43(3): 189-198. 
Silver, M. W. \& Gowing, M. M. (1991). The 'particle' flux: origins and biological components. Progress in Oceanography, 26: 75-113.

Silver, M., Pilskaln, C. \& Steinberg, D. (1991). The biologists view of sediment trap collections: problems of marine snow and living organisms. In P. Wassman, A Heiskanen \& O. Lindah (Eds.), Sediment trap studies in the Nordic Countries (pp. 76-93). Helsinki: Tvärminne Zoological Station.

Spencer, T. \& Viles, H. (2002). Bioconstruction, bioerosion and disturbance on tropical coasts: coral reefs and rocky limestone shores. Geomorphology, 48: 23-50.

Steingber, D. K., Pilskaln, C. H. \& Silver, M. W. (1998). Contribution of zooplankton associated with detritus to sediment trap 'swimmer' carbon in Monterey Bay, California, USA. Marine Ecology Progress Series, 164: 157-166.

Storlazzi, C. D., Ogston, S. A., Bothner, M. H., Field, M. E. \& Presto, M. K. (2004). Wave and tidally-driven flow and sediment flux across a fringing coral reef; Southcentral Molokai, Hawaii. Continental Shelf Research, 24: 1397-1419.

Storlazzi, C. D., Field, M. E. \& Bothner, M. H. (2011). The use (and misuse) of sediment tramps in coral reef environment: theory, observations and suggested protocols. Coral Reefs, 30: 23-38.

Szmant, A. M. (2002). Nutrient enrichment on coral reefs: is it a major cause of coral reef decline?. Estuaries, 25: 743-766.

Wilkinson, C., Green, A., Almany, J. \& Dionne, S. (2003). Monitoring coral reef marine protected areas-A practical guide on how monitoring can support effective management of MPAs. Townsville: Australian Institute of Marine Science and the IUCN Marine Program.

Wilkinson, C. (2004). Status of coral reefs of the world: 2004. Queensland: Australian Institute of Marine Science.

Young, C., Sewell, M. \& Rice, M. (2002). Atlas of marine invertebrate larvae. United States of America: Academic Press.

Zapata, F. A. 2001. Formaciones coralinas de Isla Gorgona. In L. Barrios \& M. López-Victoria (Eds.), Gorgona marina: Contribución al conocimiento de una isla única (pp. 27-40). Santa Marta: INVEMAR-Serie Publicaciones Especiales No. 7.

Zapata, F. A. \& Vargas-Ángel, B. (2003). Corals and coral reefs of the Pacific coast of Colombia. In J. Cortés (Ed.), Latin American coral reefs (pp. 419-447). Amsterdam: Elsevier Science.

Zapata, F. A., Rodríguez-Ramírez, A. \& Navas-Camacho, R. (2008). Decade-Long (1998-2007) trends in live coral cover on a Tropical Eastern Pacific coral reef at Gorgona Island, Colombia. Abstracts 11th International Coral Reef Symposium, 1: 450-451.

Zapata, F. A., Rodríguez-Ramírez, A., Caro-Zambrano, C. \& Garzón-Ferreira, J. (2010). Mid-term coral-algal dynamics and conservation status of a Gorgona Island (Tropical Eastern Pacific) coral reef. Revista de Biología Tropical, 58: 81-94. 